\title{
The Creation in Building Good News for The Society in Medan, Indonesia
}

\author{
Ahmad Qorib ${ }^{1}$, M. Yoserizal Saragih ${ }^{1}$ \\ ${ }^{1}$ Social Science Faculty, State Islamic University of Medan, Indonesia \\ yosesaragih77@gmail.com
}

\begin{abstract}
: the news has three news coverage techniques, namely reportage, interviews, library research (literature studies). Some news writing techniques that can be a basic guide for journalists are:The title of the news is as concise as possible with short and clear sentences, but can still describe the core of the story as a whole. There are $5 \mathrm{~W}+1 \mathrm{H}$ elements.Arrange news so that it can be presented with accurate, clear and interesting information. Use language that is easily understood by readers from a variety of circles.Not "patronizing" but "showing / presenting".
\end{abstract}

Keywords: news; society; rules; information

\section{Introduction}

News is the life of the mass media. The existence of mass media, both at the beginning of its birth, its development period, and even in its current era of glory so that entering the information age, is not only important but also very determines the direction of human civilization. Thus, news that gives the mass media life. Without news, mass media will have no meaning. News (news) is the main presentation of a mass media in addition to views (opinions). Finding news material and then compiling it is the main task of journalists and the editorial section of a press publication (mass media). There is no doubt that news information is needed for various purposes of human life, because of that its role is very extraordinary. We all receive a lot of information every day, however, whether all this information is news that can be broadcast in the mass media. In this case the news is information but not all information is news. To find out more details about the ins and outs of an information can be categorized as a news, then in this paper will be explained about whether the understanding of the news itself and how the form, type, source and technique of writing a story.

Newspapers are typically published daily or weekly. News magazines are also weekly, but they have a magazine format. General-interest newspapers typically publish news articlesand feature articles on national and international news as well as local news. The news includes political events and personalities, business and finance, crime, weather, and natural disasters; health and medicine, science, and computers and technology; sports; and entertainment, society, food and cooking, clothing and home fashion, and the arts.

Usually the paper is divided into sections for each of those major groupings (labeled A, B, C, and so on, with pagination prefixes yielding page numbers A1-A20, B1-B20, C1-C20, and so on). Most traditional papers also feature an editorial page containing editorials written by an editor (or by the paper's editorial board) and expressing an opinion on a public issue, opinion articles called "op-eds" written by guest writers (which are typically in the same section as the editorial), and columns that express the personal opinions of columnists, usually offering analysis and synthesis that attempts to translate the raw data of the news into information telling the reader "what it all means" and persuading them to concur. Papers also include articles which have no byline; these articles are written by staff writers. 
A wide variety of material has been published in newspapers. Besides the aforementioned news, information and opinions, they include weather forecasts; criticism and reviews of the arts (including literature, film, television, theater, fine arts, and architecture) and of local services such as restaurants; obituaries, birth notices and graduation announcements; entertainment features such as crosswords, horoscopes, editorial cartoons, gag cartoons, and comic strips; advice columns, food, and other columns; and radio and television listings (program schedules). As of 2017, newspapers may also provide information about new movies and TV shows available on streaming video services like Netflix. Newspapers have classified ad sections where people and businesses can buy small advertisements to sell goods or services; as of 2013, the huge increase in Internet websites for selling goods, such as Craigslist and eBay has led to significantly less classified ad sales for newspapers. Most newspapers are businesses, and they pay their expenses with a mixture of subscription revenue, newsstand sales, and advertising revenue (other businesses or individuals pay to place advertisements in the pages, including display ads, classified ads, and their online equivalents). Some newspapers are government-run or at least government-funded; their reliance on advertising revenue and on profitability is less critical to their survival. The editorial independence of a newspaper is thus always subject to the interests of someone, whether owners, advertisers, or a government. Some newspapers with high editorial independence, high journalism quality, and large circulation are viewed as newspapers of record.

Many newspapers, besides employing journalists on their own payrolls, also subscribe to news agencies (wire services) (such as the Associated Press, Reuters, or Agence FrancePresse), which employ journalists to find, assemble, and report the news, then sell the content to the various newspapers. This is a way to avoid duplicating the expense of reporting from around the world. Circa 2005, there were approximately 6,580 daily newspaper titles in the world selling 395 million print copies a day (in the U.S., 1,450 titles selling 55 million copies). ${ }^{[1]}$ The late 2000s-early 2010s global recession, combined with the rapid growth of free web-based alternatives, has helped cause a decline in advertising and circulation, as many papers had to retrench operations to stanch the losses. ${ }^{[2]}$ Worldwide annual revenue approached $\$ 100$ billion in $2005-7$, then plunged during the worldwide financial crisis of 2008-9. Revenue in 2016 fell to only $\$ 53$ billion, hurting every major publisher as their efforts to gain online income fell far short of the goal. ${ }^{[3]}$

The decline in advertising revenues affected both the print and online media as well as all other mediums; print advertising was once lucrative but has greatly declined, and the prices of online advertising are often lower than those of their print precursors. Besides remodeling advertising, the internet (especially the web) has also challenged the business models of the print-only era by crowdsourcing both publishing in general (sharing information with others) and, more specifically, journalism (the work of finding, assembling, and reporting the news). In addition, the rise of news aggregators, which bundle linked articles from many online newspapers and other sources, influences the flow of web traffic. Increasing paywalling of online newspapers may be counteracting those effects. The oldest newspaper still published is the Ordinari Post Tijdender, which was established in Stockholm in 1645. 


\section{Literature Review}

\subsection{Definition of News}

News is as a narrative correctly and impartially from facts that have important and new meanings that can attract the attention of news readers in the newspaper. The definition of news according to some experts is:

According to Eric C. Hepwood, who gives a limit: "News is the first report of an important event that can attract public attention." Dean M. L Lyle Spencer in his book entitled News Writings states that: "News can be defined as any fact that is accurate or an idea that can draw attention to a number of readers. "

While Mitchel V. Charnley in his book Reporting edition III states: "News is a timely report of facts or opinions that have an attraction or important thing or both for the wider community."

Other experts in other fields of journalism who provide understanding of the news, but almost all agree that the elements contained in a news include the scope of these opinions such as: fact, accurate, idea, timely, interesting, important, opinions and a number of readers, listeners and viewers are things that need attention.

From some definitions above, it can be concluded that "News is a fact or an idea or an actual opinion that attracts readers, listeners and viewers."

To understand the news, the following points are important to know:

a. News must be factual, but not all facts are news.

b. News may be in the form of opinions, especially from figures or authorities in certain fields.

c. The main news is about people, about what they say and do.

d. News is not always a report of current events.

e. Anything that is important news for a community or university may not be important or less important or even has no news value for the community or for other universities.

f. Anything that becomes news in one community or university may also be news for every other community or university.

g. What is news today is often no longer the news the next day.

$\mathrm{h}$. What is considered by someone as news is not necessarily considered by others as news.

i. Two important factors for news, attractiveness and significance, are not always synonymous.

\subsection{Forms of News}

News in print and electronic media is different, though basically the same, like using the provisions of $5 \mathrm{~W}+\mathrm{H}$.

a. News of print media: News in printed mass media is news contained in newspapers, magazines, tabloids, bulletins. The news is in the form of writing and unmoving images (photo).

b. Newspaper news: Some general forms of print media news, especially newspapers, according to Assegaf (1983) and Supriyanto (1986) are as follows:

i. Spot News (short news): Spot News is news that is written briefly because it is not large in the appeal of the news or the impact of the news is not great for the public. For example around the area, short crimes, footage of sports, etc.

ii. Straight news (direct news):Straight news is quite important news, usually from events and / or statements (comments) from one, two or more sources. Inside the 
straight news is known as an inverted pyramid shape. In relation to the reverse pyramid, the news can be divided into news: very important, important, rather important, and not important.

iii. Spot press: Spot News is news that is written briefly because it is not large in the appeal of the news or the impact of the news is not great for the public. For example around the area, short crimes, footage of sports, etc.

iv. Stopper (closing news):Stopper is news that is only written short because the data obtained is indeed impossible to develop anymore and is usually used as a cover page (print media) or spend broadcast time (electronic media)

v. Depth news (in-depth news): In addition to in reporting depth or news depth, there is also this form of news that calls it comprehensive news. This is complete and indepth news (usually explored in teams). The news is extracted from certain cases towards the background of the cause of the case (investigative) and towards the consequences (front) and the case (interpretative). Writing news like this is done because the importance of the news is revealed and has a major impact on people's lives.

vi. Analysis news (news analysis):Analysis news is news that is written with analysis from the editor in chief or an outsider (the media expert). Usually this news is interesting, although it is not related to the interests of the people.

vii. Feature: Actually there is no definite definition of this feature. William R. Rivvers mentions, "naked" stories or facts are called news; editorials, columns and reviews are called articles.

c. Tabloid News and Magazines:Tabloids and Magazines rarely write spot news or straight news, but more often depth news, features, and analysis news. In fact, not infrequently is a combination of in-depth news (depth news) written in the style of features or analysis news written in feature style.

d. Electronic media news

i. Radio News

The broadcast of news on radio media, stated Romli (2004) is somewhat different from the print media because radio media can broadcast live (live) from the scene or it can also read the news in the studio. Some forms of electronic media include the following:

1) Report directly from the scene

2) Sound bite is a piece of interview broadcast on a news program.

3) Read the manuscript is a text written in advance (as in print), then read the news presenter.

The power of radio lies in the sound heard by the public. Channels (channels) in the process of communication via radio are public voice and hearing. Therefore, news on radio, as well as radio broadcast programs, must pay attention to what is called "sound quality" so that it does not become a communication obstacle that causes misunderstanding. This is closely related to radio identity as an auditive media.

Based on these characteristics, in addition to the general requirements for news, news on radio basically has specific requirements, namely:

a) Not wrong in terms of substance (content). Therefore, before it was reported, both editors and publishers had to check recheck several times because radio news did not recognize "errata" as in print media. For example the announcer said the sentence L: 
"Sorry, in the news that we broadcast yesterday at twelve o'clock there was a mistake said, the name of the killer should not be Nuubis but Lubis".

b) Clarity of news sources. If the newspaper is allowed to say "according to sources that are worthy of trust" or "according to someone close", then it is strictly prohibited in radio news. Those "reliable sources", whose names are "close people" must be clearly stated. If you don't dare to mention it, you don't have to be a news source.

c) Upholding morality. Even though it remains based on facts, it must be delivered with an expression that upholds decency. For example, there was the fact that a president cursed the demonstrators by saying: "You rascals, you don't know the rules, are paid by people who don't like me." This fact should be packaged with sentences, for example "The President could scold the demonstrators".

ii.Television News

\section{Types of News}

\section{Discussion}

News in general can be categorized into three parts: hard news, soft news and investigative reports.

\section{a. Hard News}

Hard News (heavy news) is news about events that are considered important for the community both as individuals, groups and organizations. The news is for example about the enactment of a new government policy. This, of course, will concern many people so that people want to know it. Because it must be reported immediately.

In general, hard news data is still easy to obtain, because all of them can still be transparent, although in some cases reporters also experience the actual data. Such things usually occur when there is a disaster of toxic gas leaks that cause the death of many people.

\section{b. Soft News}

Soft News (light news) is often referred to as a feature that is news that is not bound by actuality but has an attraction for viewers. This kind of news focuses more on the amazing or surprising viewers. He also raises fears even fear or might cause sympathy. The object can be humans, animals, objects, places or anything that attracts the attention of viewers. For television, this light barita is very necessary in every presentation of a news bulletin. This is because light news can also function as a distraction between the heavy news broadcast at the beginning of the presentation. Psychologically, viewers who get heavy news from the beginning to the end will feel tense because it needs an interval.

\section{c. Investigative Reports}

Investigative Reports, also called investigative reports, are exclusive types of news. The data cannot be obtained on the surface, but must be carried out based on investigation. So that the presentation of news like this requires a long time and certainly will consume the energy of the reporter.

The news of this investigation is very interesting because it is not easy to express it. A reporter to be able to do the task must have many sources of insiders who are guaranteed not to be exposed because of their personal safety. 


\section{News Sources}

News sources are things that give birth to news. Something that can be human, place and nature and events. The news hunters known as journalists are always aware of the news sources in the sense of waiting for the birth of the news from its sources.

a. Humans as news sources

Not all humans are news sources. It is hard to imagine if every human being becomes a source of news, because it is impossible for journalists to be aware of every human being. Therefore in the context of news sources, journalists classify humans as follows:

1. World leaders (heads of State / governments of major countries or charismatic figures of influential countries). Example: US President George W. Bush and Singapore Senior Minister Lee Kuan Yew. All their activities and statements can become news.

2. Heads of State / government and figures who are "at odds" with the world leaders mentioned above. Example: Libyan President Moammar Khadafi, Iraqi President Saddam Hussein (before being invaded by the US), Malaysian Prime Minister Mahathir Mohammad, Al-Qadiah Leader Usamah bin Ladin.

3. Popular figures who devote themselves to the nation or humanity. Example: Palestinian President Yasser Arafat and the late Mother Theresa.

4. Resistance leaders over a regime or government. Example: Aung San Suu Kyi in Myanmar, Nur Misuari in the Philippines and Tenku Abdullah Syafei (late) in Aceh.

5. Individuals whose actions have shocked the world or the local community. Example: science inventors or inventors of historical objects, murderers, corruptors and so on.

6. Leaders of political, religious and community organizations.

7. Historical actors who are still alive.

8. Eyewitnesses of an event that made news.

9. Victims of an event.

10. International, regional, local celebrities.

11. Others.

\section{b. Place as a news source}

A place in this sense is the place where an event becomes news and a place that has great opportunity for the birth of the news. In the first sense the place can be everywhere, even in remote places that have never been affected by the community. For example, a remote village suddenly became overcrowded by reporters and became the material for writing journalists in the form of "village profiles" because the village was used as a hideout for perpetrators of major crimes.

The place in the second sense is the place that has a great chance for the birth of the news, it has become a list in the journalists' notes. These places are the center of human activity as a source of news, for example the presidential palace

\section{Conclusion}

Experts in the field of journalism provide an understanding of the news, but almost all agree that the elements contained in a news include: facts, accurate, ideas, timely, interesting, important, opinions and a number of readers, listeners and viewers are things things that need attention. From the opinion of journalistic experts, it can be concluded that "News is a fact or an idea or an actual opinion that attracts readers, listeners and viewers. 
News forms include news from print media, electronic media news, and online media. Cetar media news consists of newspapers, tabloids and magazines. Electronic media news consists of radio and television.

In general, news can be categorized into three parts: hard news, soft news and investigative reports. While news can be obtained from several sources, namely news sourced from humans, places, nature and events.

\section{References}

Mondry, Pemahaman Teori dan Praktik Jurnalistik, Bogor: Ghalia Indonesia, 2008

Muda, Deddy Iskandar, Jurnalistik Televisi: Menjadi Reporter Profesional, Bandung: PT Remaja Ruda Karya Offset, 2008

Pareno, Sam Abede, Manajemen Berita antara Idealisme dan Realita. Surabaya: Papyrus, 2003

Rolnicki, Tom E., Pengantar Dasar Jurnalisme (Scholastic Journalism), Jakarata: Kencana Prenada Media Group, 2008

Romli, Asep Syamsul M., Jurnalistik Praktis untuk Pemula, Bandung: PT Remaja Rosdakarya, 2009

Dja'far H. Assegaf, Jurnalistik Masa Kini, Jakarta : Ghalia Indonesia, 1985 